\title{
THE POSITION OF THE WORKERS' OR LABORERS' SEVERANCE PAY AND OTHER RIGHTS IN THE BANKRUPTCY OF A COMPANY
}

\author{
Sonhaji \\ Faculty of Law, Diponegoro University \\ sonhajimuh19@gmail.com
}

\begin{abstract}
Bankruptcy shall mean general confiscation of all assets of a debtor who could no longer afford to pay the debts that are due and could be billed. In Indonesia, bankruptcy is already known before 1945. Bankruptcy is Commercial Court ruling which put all assets of a debtor in a public attachment status thereafter the appointed curator could manage and liquidate the assets of the bankrupt debtor (bankruptcy properties) which would be sold and distributed to all creditors based on their respective levels of entitlement including the wages owed and other rights (Severance pay, gratuity and other compensation benefits). Problems would rise if the company hiring the laborers is declared bankrupt by the Commercial Court. In such circumstances, wage repayments or remunerations to the laborers became an interesting topic to be studied. The company and the government are responsible upon the fulfillment of the laborers' wage rights. In case that responsibility is not fulfilled, then there had been a violation of the rights of the laborers' welfare and violations and blasphemy of human rights. In reality, the laborers' wages sometimes are not paid by the company where they worked because it had bankrupt and is unable to pay, because the company did not want to pay even though there is a decision from the Industrial Relations Court which required the employer (company) to pay the wages or the severance pays.
\end{abstract}

\section{Introduction}

Bankruptcy is general confiscation of all assets of a debtor who could no longer afford to pay the debts that are due and could be billed. In Indonesia, bankruptcy is already known before 1945. The filing of a bankruptcy statement against the debtor must meet the requirements stated in Article 2 paragraph (2) of Law Number 37 of 2004 on Bankruptcy and Suspension of Debt Payment Obligation (hereinafter called UUK-PKPU), namely the debtor must have two creditors or more, the debtor does not pay off at least one debt to one of its creditors, and debt is not paid if it should have matured and can be charged (due and payable). Bankruptcy is Commercial Court decision which put all assets of a debtor in a public attachment status thereafter the appointed curator could manage and liquidate the assets of the bankrupt debtor (bankruptcy properties) which would be sold and distributed to all creditors based on their respective levels of entitlement.

Problems will rise if the company hiring the laborers is declared bankrupt by the Commercial Court decision. In such circumstances, wage repayments or remunerations to the laborers become an interesting topic to be studied. The company and the government are responsible upon the 
fulfillment of the laborers' wage rights. In case that responsibility is not fulfilled, then there has been a violation of the rights of the laborers' welfare and violations and blasphemy of human rights.

In reality, the laborers' wages sometimes are not paid by the company where they work because it has gone bankrupt and is unable to pay, because the company does not want to pay even though there is a decision from the Industrial Relations Court which requires the employer (company) to pay the wages or the severance pays.

In the midst of the search for justice and the primacy of the legal certainty principles of the laborers' wage position as the debts of the bankrupt properties, it becomes more strange (inconsistent) when referring to the reasons for the consideration of the Court decision and in some cases, this becomes very interesting matters to be studied. Some cases concerning the practice of the laborers' rights in the form of the payments of wages, severance pay, gratuity, and compensation as the debts of bankruptcy properties on the court decision will be describe in this article.

Those cases show that there are so many bankruptcy cases which involve the workers regarding the realization of the workers' wages, severance pay, gratuity, and compensation payments which is difficult to be understood either from the juridical point $f$ view or the point of view of the justice.

Based on the background which has been described above, the interesting thing to be studied with a title is: "THE POSITION OF THE WORKERS' OR LABORERS' SEVERANCE PAY AND OTHER RIGHTS IN THE BANKRUPTCY OF A COMPANY".

Based on the background of the study above, the problems of the study can be formulated as follows:

1. What is the position of the workers' or laborers' severance pay and other rights in the bankruptcy of a company according to the prevailing laws and regulations?

2. How is the implementation of the legal provisions on the position of the workers' or laborers' severance pay and other rights in the decision of the bankruptcy case?

\section{Method}

In the research of the position of the workers' or laborers' severance pay and other rights in the bankruptcy of a company, the researcher used sociological juridical approach, which is an approach aimed to gain knowledge on how law and society relations and the factors frequently influenced the 
implementation of the law in the society is. This approach is done directly in the field in order to get objective data which would be used as primary data. ${ }^{1}$

This sociological juridical research used two data sources, namely the secondary data for the first data and the primary data for the second one which is obtained directly from the field. ${ }^{2}$

\section{Theoretical Framework}

\section{The General Review of Bankruptcy}

\section{The Notion of Bankruptcy}

If the history of the bankruptcy laws is traced, it could be seen that the law of bankruptcy itself had existed since Roman times ${ }^{3}$. The word "bankrupt" in English came from the Italian law called banca rupta ${ }^{4}$. In medieval Europe, a bankruptcy practice took place by destroying bankers of the bankers or the merchants who fled with the treasures of their creditors. According to Poerwadarminta, "insolvent" meant "bankrupt", where "bankrupt" meant that a company, store, etc suffered great losses to the point of failing. In Law Number 4 of 1998 Jo. Law Number 37 of 2004 on Bankruptcy, there is no provisions or formulas explaining the definition of bankrupt or bankruptcy, however the definition of Bankruptcy in Dutch and English each of which is translated as follows:

1. Bankruptcy in Dutch is Faillisement, staat van faillisement, which meant the state of bankruptcy of a debtor.

2. In the Black Law Dictionary, it is insolvent or bankrupt. According to Professor Radin in his book entitled The Nature of Bankruptcy, as quoted by Jordan et al, the purpose of all bankruptcy laws is to provide a collective forum to sort out the rights of various creditors on the insufficient assets of debtors 5 .

\footnotetext{
${ }^{1}$ Soerjono Soekanto, Pengantar Penelitian Hukum, (Jakarta : UI Press, 1986), page.4

${ }^{2}$ Abdulkadir Muhammad, Hukum dan Penelitian Hukum, (Bandung : PT. Citra Aditya Bakti , 2004), page 53.

${ }^{3}$ Sunarni, Perbandingan Sistem Hukum Kepailitan antara Indonesia (Civil Law System) dengan Amerika Serikat (Common Law System), (Fakultas Hukum Unversitas Sumatera Utara, 2004). page10, quoted from Douglas G. Bird, Cases, Problems, and Materials on Bankruptcy, Boston, USA : Little, Brown and Company, 1985, page 21

${ }^{4}$ Jono, Hukum Kepailitan, (Jakarta: Sinar Grafika, 2008), page 1.3 Ramlan Ginting, Kewenangan Tunggal Bank Indonesia Dalam Kepailitan Bank, "Buletin Hukum Perbankan danKebanksentralan", Vol.2 No.2, Agustus 2001, pg.1, mengutip dari W.J.S. Poerwadarminta, Kamus Umum BahasaIndonesia, Balai Pustaka, Jakarta, 1999.

${ }^{5}$ Louis E. Levinthal, The Early History of Bankruptcy Law in Jordan et al. Bankruptcy, (New York : Foundation Press, 1993:2)
} 


\section{The Purpose of Bankruptcy}

According to Rudhi Prasetyo in Peter (1996: 5), the bankruptcy institutions are expected to serve to prevent the arbitrary occurrence of the creditor party to force the debtor in various ways to pay the debt ${ }^{6}$. The purposes of bankruptcy as stated in the laws are:

1. To prevent creditors from illegally claiming the debtor's assets when there are more than one creditor at the same time.

2. To prevent creditors holding security right in respect of a property from selling the debtor's property without considering the interest of both the debtor and other creditors.

3. To avoid fraud or dishonest practices by one of the creditors or by the debtor himself which harm the interest of the other creditors or give advantages to one cerain creditor..

4. To give protections towards the concurrent creditors to obtain their rights in connection with the validity of the guarantee principle.

5. To give chances to the debtor and the creditors to negotiate in making a debt restructuring agreement.

\section{The Conditions of Bankruptcy}

The terms to apply a request of a declaration of bankruptcy against a debtor are stipulated in Article 2 paragraph (1) UUK-PKPU, namely: "A debtor having two or more creditors and failing to pay at least one debt which has matured and became payable, shall be declared bankrupt through a Court decision, either at his own petition or at the request of one or more of his creditors". The terms of the declaration of bankruptcy could be explained as follows:

a. The existence of two or more creditors (Concursus Creditorum)

The requirement that the debtor should have at least two creditors is closely related to the philosophical birth of bankruptcy law, namely that bankruptcy law is the realization of Article 1132 Civil Code ${ }^{7}$.

b. The existence of a debt

Based on the explanation of Article 2 paragraph (1) UUK-PKPU, the phrase "debt which has become due and collectable" should mean the obligation to pay debt that had become due,

\footnotetext{
${ }^{6}$ Hartini,R, Hukum Kepailitan (Malang, UMMPress,2007), page 22

${ }^{7}$ Jono, Hukum Kepailitan, (Jakarta:Sinar Grafika, 2008), page. 5.
} 
either under the contract, accelerated or due to the sanctions imposed by the regulatory body or decision of the court, arbitrator or panel of arbitrators.

\section{The Parties who Could File Bankruptcy}

As referred to in Article 2 paragraph (1) UUK-PKPU, the parties who could file a petition for declaration of bankruptcy are:

a. the Debtor himself

As set forth in Article 2 paragraph (1) UUK-PKPU, the filing of a petition of declaration of bankruptcy against a debtor might also be filed at his own petition.

b. the Request of one or more of the creditors

In the explanation of Article 2 paragraph (1) UUK-PKPU, the "Creditor" in this paragraph should mean concurrent creditor, separated creditor, and preferred creditor. Specifically for separated creditor and preferred creditor, they may file a petition for declaration of bankruptcy without losing their collateral right in respect of the Debtor's properties and their prioritized right.

c. the Court

The petition for a declaration of bankruptcy might also be filed by the Public Prosecutor for the public interest. As referred to in the explanation of Article 2 paragraph (1) UUK-PKPU, "Public interest" is the interest of the nation and the state and/or public at large, for example: The debtor escapes; The debtor hide part of his assets; The debtor has indebtedness to State Enterpriser legal entities that raise funds from the society; The debtor owns money that come from funds raised from the public at large scale; The debtor demonstrates no good faith or is uncooperative in the settlement of his debt that has become mature; or Any other cases that in the opinion of the attorney office concern public interest.

d. the Bank of Indonesia

In the event that the Debtor is in the form of a bank, the petition for a declaration of bankruptcy may only be filed by Bank Indonesia (Article 2 paragraph (3) UUK-PKPU) solely based on the evaluation of the financial condition and banking condition in overall.

e. the Capital Market Supervisory Board

In the event that the Debtor is in the form of a Securities Company, Stock Exchange, Clearing and Custodian Institution, Settlement and Depository Institution, the petition for a 
declaration of bankruptcy may only be filed by the Capital Market Supervisory Bard as referred to in Article 2 paragraph (4) UUK-PKPU because the institution engages in activities that concern the people's funds that are invested in the securities under the supervision of Capital Market Supervisory Board. Furthermore, Capital Market Supervisory Board also possesses full authority to file petition for declaration of bankruptcy against institutions under its supervision, like bank of Indonesia's authority towards banks.

f. the Minister of Finance

In the event that the Debtor is in the form of Insurance Company, Reassurance Company, Pension Funds, or State-Owned Enterprise engaged in the sectors of public interest, the petition for a declaration of bankruptcy may only be filed by the Minister of Finance. The provision as set forth in Article 2 paragraph (5) UUK-PKPU is needed to build the public trust in such efforts.

\section{The Consequences of Bankruptcy}

After the decision of the petition of bankruptcy declaration is pronounced by a Commercial Court Judge, a number of legal consequences rose, including 8 :

a. the Consequences of Bankruptcy against the Bankrupt Debtor

The Article 24 paragraph (1) UUK-PKPU regulated that a Bankrupt Debtor shall by law forfeit his right to control and manage his assets included in his bankruptcy as of the date of the pronouncement of the bankruptcy declaration decision. It should be noted with the decision of becoming the bankrupt debtor did not mean that the debtor lost his right to be able to perform any legal acts in the field of civil law ${ }^{9}$. Therefore, as of the date of the pronouncement of the bankruptcy declaration decision only the Bankrupt Debtor's assets which are under supervisions (under the authorization and management of other parties), whereas the Bankrupt Debtor himself is not under the supervision.

In case that the bankruptcy declaration decision against the company management or the debtor or the legal entity, then the authority of the board directors of a limited liability company and other legal entities to manage the debtor's company or legal entity is "stuck", notwithstanding they

\footnotetext{
${ }^{8}$ Sutan Remy Sjahdeini., Op cit, page 190. 28

${ }^{9}$ Loc Cit.
} 
kept the ownership ${ }^{10}$. The official administrator is where everything is decided and carried out by the Curator. In case that the Debtor as referred to in the explanation of Article 24 paragraph (4) UUK-PKPU is a limited liability company, the organs of the said company shall function as usual provided anything that may causes reduction in the bankruptcy estate shall be under the authority of the Curator ${ }^{11}$. It meant that the directors of the limited liability company could only take legal action as long as it concerned with the income of the company, however in terms of spending the money on the burden of the bankrupt properties only the Curator had the right to make a decision to approve the payments and given that view the payments approved by the Curator could still be done by the directors of the limited liability company.

b. the Consequences of the Bankrupt Debtor's Wealth

The bankrupt debtor's wealth included in the bankrupt properties are under the public confiscation, which meant that the confiscation applied to anyone not only a certain party, but also confiscation of guarantee decided by the civil judge in respect of the plaintiff's petition in a civil dispute $^{12}$. As referred to in Article 21 UUK-PKPU, the bankruptcy shall include the total wealth of the Bankrupt Debtor at the time of the bankruptcy declaration, together with that which he acquires during the bankruptcy (except the ones explicitly excluded from the bankruptcy properties by UUK-PKPU). For the sake of humanity towards the debtor (the individual debtor), there are some properties of the bankrupt debtor which are excluded from the bankruptcy properties by the UUK-PKPU. It meant that there are some some properties of the bankrupt debtor which are excluded from the bankruptcy properties as set forth in Article 22 UUK-PKPU, namely:

a. Any properties, including animal, that are badly needed by the Debtor in connection with his or her job, his or her equipment, medical equipment for health purpose, bed and related appliances that are used by the Debtor and his or her family, and food supply for 30 (thirty) days for the Debtor and his or her family that are existing at his or her place;

b. Anything earned by the Debtor from his or her work as a salary for his or her position or service, as a fee, pension, or allowance as may be determined by the Supervisory Judge; or

c. Any money given to the Debtor to enable him or her to provide maintenance as required by the prevailing law.

\footnotetext{
${ }^{10}$ Ibi,d page 191

${ }^{11}$ Loc Cit

${ }^{12}$ Ibid, page 193
} 


\section{The Management and Settlement of the Bankruptcy Assets}

\section{a. the Bankruptcy assets and the existence of which beyond the bankruptcy properties}

The bankruptcy assets ${ }^{13}$ are the assets of the debtor which are declared bankrupt according to the Court decision. The provision in Article 21 UUK-PKPU explicitly stated that the bankruptcy shall include the total wealth of the Bankrupt Debtor at the time of the bankruptcy declaration, together with that which he acquires during the bankruptcy, notwithstanding Article 22 UUKPKPU excluded some kinds of debtor's properties from the bankruptcy assets such as:

1. Any properties as referred to in Article 451 number 2 until 5 of the Reglement of the Civil Events, the money or the annual salary mentioned in Article 749 letter C;

2. Anything earned by the Debtor from his or her work as a salary for his or her position or service, as a fee, pension, or allowance as may be determined by the Supervisory Judge;

3. Any money given to the Debtor to enable him or her to provide maintenance as required by the prevailing law;

4. The amount of money determined by the Supervisory Judge from the right to enjoy the proceeds as referred to in Article 311 Indonesian Civil Code in order to pay the duties mentioned in Article 312 Indonesian Civil Code; and

5. The allowance of the Bankrupt Debtor as referred to in Article 318 Indonesian Civil Code received from the income of the children.

\section{The Overview of Debtors and Creditors}

a. the Meaning of Debtor

The definition of debtor as referred to in Article 1 number (3) UUK-PKPU is a person who has indebtedness for which it might be demanded to pay before the court. Besides the meaning of debtor, there is the meaning of bankrupt debtor in Article 1 number (4) UUK-PKPU, namely a debtor who has been declared as bankrupt with judicial decision.

b. the Meaning of Creditor

As referred to in Article 1 number (2) UKK-PKPU Creditor should mean the person who has receivables from an agreement or a law that may be collected before the court. The creditors in the

\footnotetext{
${ }^{13}$ Yani A \& Widjaja Gunawan, Seri Hukum Bisnis Kepailitan., Jakarta: PT.Raja Grafindo Persada 2004.
} 
bankruptcy itself are divided into three, namely concurrent creditor, separated creditor, and preferred creditor, where the difference as referred to in Article 1132 the Civil Code is said that "unless there exists a legal order of priority among the creditors".

With that sentence, there are certain creditors who are granted higher authority over the others.

\section{Preferred Creditors}

Preferred creditors (which are privileged) are ${ }^{14}$ creditors by the law applicable to one creditor over the other, based upon the nature of the debt. The preferred creditors are the creditors with a privilege, namely a right acknowledged by the law applicable to one creditor over the other. Regarding the debts with privileges could be seen in Article 1139 and 1149 of the Civil Code. The priority of debts in respect of certain specific assets should be as follows; first, court charges which specifically result from the disposal of a movable or immovable asset. These shall be paid from the proceeds of the sale of the assets over all other priority debts, and even over a pledge or mortgage. Second, the rent from immovable assets, the costs incurred in the repairs for which the lessee is responsible, including anything related to the compliance with the provisions of the lease agreement. The third is the unpaid consideration for the sale of movable assets. Fourth, the costs incurred in the maintenance of the property. Fifth, the wages owing to laborers for the work carried out to the property. Sixth, anything delivered to a traveler by an innkeeper. The seventh is freight costs and additional charges. Eighth, any amount due to bricklayers, carpenters and other workmen as a result of the renovation, addition to and repairs of immovable assets, including a debt which is in existence for not more than three years, and the title to a plot which has been held by the debtor. Ninth, the compensation and payment for which public officials are responsible, due to negligence, error, violations and misdemeanor, which are committed during the course of their service. The Article 1149 of the Civil Code determined that the priority loans in regard to the movable and immovable assets in general shall be as follows and shall be claimed in the following order:

First, the legal charges, exclusively caused by sale and saving of the estate; these shall have priority over pledges and mortgages. Secondly, the funeral charges, if they are excessive, without prejudice to the authority of the judges. Third, all costs incurred in relation to the last illness. Fourth, the laborers' wages during the last year and that which is due for the current year, including the amount of any raise of such wage pursuant to article 1602 of the Civil Code. Fifth, the debt claim

\footnotetext{
${ }^{14}$ Kartini Muljadi, Kreditor Preferens dan Kreditor Separatis Dalam Kepailitan,”Undang-Undang Kepailitan danPerkembangannya : Proceeding Rangkaian Lokakarya Terbatas Masalah-Masalah Kepailitan dan Wawasan Hukum Bisnis Lainnya Tahun 2004 : Jakarta 26-28 Januari 2004", Jakarta:Pusat Pengkajian Hukum, 2005, page 65. look in Article 1133, 1134 Civil Code
} 
against delivery of food to the debtor and his family, during the last six months. Sixth, the debt claims of boarding schools for the most recent year and seventh the debt claims of minors or individuals under conservatorship filed against their guardians and conservators.

2. Separated Creditors

Separated creditors are ${ }^{15}$ the creditors who held the right of property herein the Civil Code referred to as pledge or mortgage. At present, Indonesia's legal guarantee system recognized four kinds of guarantee, namely mortgages, pledges, encumbrance rights, and fiduciary guarantee. The mortgages are regulated in Article 1162 until Article 1232 of the Civil Code, which is applied to ships with a minimum size of $20 \mathrm{~m} 3$ and had been registered in Syahbandar and the airborne aircraft. The pledges are regulated in Article 1150 until Article 1160 of the Civil Code which is applied to movable assets. The encumbrance rights are regulated in Law Number 4 of 1996 regarding Encumbrance Right over Land and Land-related Objects which is a guarantee of certain land rights and the material inherent in the land. On the other hand, the fiduciary is regulated in Law Number 42 of 1999 on Fiduciary Guarantee which the goods being the Fiduciary guarantee object could not be guaranteed by pledges, mortgages, and encumbrance rights.

\section{Concurrent Creditors}

The concurrent creditor is regulated in Article 1132 of the Civil Code. The concurrent creditors are the creditors with joint guarantee which meant that the proceeds thereof shall be divided among the creditors in proportion to their loan (without the privilege possessed by the separated creditors who owned the right to self-sell or execute collateral objects without a court decision (parate execution). That right is to:

a. Pledge regulated in Article 1155 paragraph (1) of the Civil Code;

b. Mortgage regulated in Article 1178 paragraph (2) of the Civil Code;

c. Encumbrance right regulated in Article 6 jo. Article 20 paragraph (1) letter a of the Law of Encumbrance Right; and

d. Fiduciary guarantee regulated in Article 29 paragraph (1) letter b of Fiduciary Law.

The authority in encumbrance right and pledge is given based on the agreement of collateral granting between the bearer of the guarantee or the first party and the guarantor. In mortgage and

${ }^{15}$ Ibid, page 168 
fiduciary guarantee, such authority is granted under a preceding law calculated based on the amount of each debt compared to their total debts over the debtor's assets ${ }^{16}$.

\section{The Position of the Workers or the Laborers based on the Principle of Justice}

Indonesia could also be called as a developed country, this could be seen in the preamble of 1945 Constitution of the Republic of Indonesia in the fourth paragraph, stated that "pursuant to which, in order to form a Government of the State of Indonesia that shall protect the whole people of Indonesia and the entire homeland of Indonesia, and in order to advance general prosperity, to develop the nation's intellectual life, and to contribute to the implementation of a world order based on freedom, lasting peace and social justice, Indonesia's National Independence shall be laid down in a Constitution of the State of Indonesia, which is to be established as the State of the Republic of Indonesia with sovereignty of the people and based on the belief in the One and Only God, on just and civilized humanity, on the unity of Indonesia and on democratic rule that is guided by the strength of wisdom resulting from deliberation / representation, so as to realize social justice for all the people of Indonesia".

Based on the Welfare State theory of Krenenburg, the goals of the State is not only to maintain the lawful order, but also to actively pursue the prosperity and happiness of its people and to organize righteous and prosperous society. It is also stated that the efforts to achieve the goals of the State are based on equitable and balanced justice. The government should be able to recognize what the needs, problems, desires, interests, and aspirations of the people well and correctly are because the policies which are made would reflect on what are the interests and aspirations of the people.

In accordance with what Kreanenburg said, the preamble of the 1945 Constitution of the Republic of Indonesia had accommodated the purpose of the welfare state. First, it is not just maintaining the legal order. This could be reflected from the statement of Indonesian Government that shall protect the whole people of Indonesia and the entire homeland of Indonesia. Second, it also strived for the welfare and happiness of its people. This could be reflected on the State's duty to advance general prosperity, to develop the nation's intellectual life, and to contribute to the implementation of a world order based on freedom, lasting peace and social justice.

\footnotetext{
${ }^{16}$ Ibid, page 164-165
} 
In order to achieve all of that Kranenburg stated that the goals of the State should be based on equitable and balanced justice, this could be reflected from the body of the preamble of the 1945 Constitution especially in Article 1 paragraph (3) the Constitutional Law of the Republic of Indonesia. The state is the highest organization among a group or several groups of people who had the ideal to unite life within a certain area, and had a sovereign government ${ }^{17}$. Regarding the task of the State is divided into three groups. First, the State should provide protection to the population in a particular region. Secondly, the State supported or directly provided various services of the social life in the field of social, economic, and culture.

Third, the State became an impartial referee between the conflicting parties in the society and provided a juridical system that guaranteed the basic justice in the community relations ${ }^{18}$. The duty of the State according to the current modern ideology (in a welfare state or social service state) is to organize the public interest to provide prosperity and welfare as much as possible based on the justice in the State law $^{19}$. Based on Krenenburg's opinion on the purpose of the State and the third State's duty, namely the purpose of the State which is based on equitable and balance justice and the State became an impartial referee between the conflicting parties in society and provided a judicial system that guaranteed basic justice in community relations. In this case, the role of the State is reflected in the judicial function, especially the courts. The Courts must be able to provide justice for every justice seeker. However, sometimes justice is not achieved because of the inconsistency of a decision on a problem.

The injustice in the bankruptcy cases arose when the parties of interest in bankruptcy had different interpretations of the rules governing the same issue so that there is essentially no basic justice for the parties.

\section{Results and Discussions}

\section{The Provisions on the Rule of Law on the Status of Wages and Other Rights}

\section{The Laborers in Several Decision of Declaring Bankruptcy in Indonesia}

Wages, including unpaid wages and other entitlements (severance pay, gratuity and compensation pay) as referred to in Article 39 UUK-PKPU, are called the debt of the bankrupt

\footnotetext{
${ }^{17}$ Moh. Mahfud MD,asar dan Struktur ketatanegaraan Indonesia (edisi revisi),(Jakarta :penerbit,Renaka Cipta ,2000), p. 64

18 Y.Sri Pudyatmoko, Perizinan,Problem dan Upaya Pembenahan, PT. (Jakarta : Gramedia Widiarsana Indonesia , 2009), p.1

19 Amrah Muslimin ,Berapa Asas dan dan Pengertian Pokok Tentang Administrasi dan Hukum Administrasi,(Bandung: Alumni, Bandung 1985), p. 110
} 
property. Even though it is not explicitly regulated the laborers' position as one of the creditors themselves, however in the Civil Code had explained about their position in this matter as one of the creditors. Based on the rules in the society, there are still so many bankruptcy cases related to the Wages disputes and other entitlements (severance pay, gratuity and compensation pay) and employment and other rights (severance pay, gratuity and compensation pay) as a debt of insolvent property therein, either submitted by the workers or from the companies themselves, most of them reached to the Supreme Court.

The payments of wages and the other entitlements (severance pay, gratuity and compensation pay) in the Insolvency Circumstances in Government Regulation Number 78 Year 2015 concerning Manpower Wage are regulated in:

Article 37

(1) For Employer who has been declared bankrupt based on a decision by the court, the Wage and other allowances based on the rights of Worker/Laborer shall be regarded as the liability that is subject to the priority for the first payment.

(2) The Wage of Worker/Laborer as cited in paragraph (1) shall be prioritized for the settlement of payment as in accordance with the prevailing laws and regulations.

(3) The other rights of the Worker/Laborer as cited in paragraph (1) shall be prioritized for the settlement of payment after the settlement of payment to creditors who have rights to guarantee of payment.

Article 38

In case that the Worker/Laborer is in bankruptcy, the Wage and all the payments based on the work relationship shall not be included in the bankruptcy except another decision by the Judge as long as the amount is no greater than 25 (twenty five) percent of the Wage and all the payments based on the work deal or relationship that is subject to payment.

\section{The Constitutional Court Decision Number 67/PUU-XII-2013 on Material Test of Article 95 Paragraph (4) Law Number 13 Year 2003 on Employment}

- Article 95 paragraph (4) Law number 13 year 2003 contradicted to Article 28d paragraph (1) of the 1945 Constitution which stated that each person has the right to recognition, security, protection and certainty under the law that shall be just and treat everybody as equal before the law; 
- Article 28i paragraph (2) stated that each person has the right to be free from acts of discrimination based on what grounds ever and shall be entitled to protection against such discriminative treatment.

The Decisions of the Judges:

To grant the petitions of the petitioners for some;

1. Article 95 paragraph (4) Law number 13 year 2003 on Employment (Supplement Number 4297 to the State Gazette of the Republic of Indonesia Year 2003 Number 39) contradicted to the 1945 Constitution of the Republic of Indonesia, as long as it is not interpreted that "the payment of the indebted wages of the workers should take precedence over all types of creditors including the bills of the separated creditors, the bills of the State rights, the bills of the auction offices and the state formed enterprises, while the payment of the rights of other workers took precedence over all bills including the bills of the State rights, the bills of the auction offices and the state formed enterprises, except the bills of the separated creditors";

2. Article 95 paragraph (4) Law number 13 year 2003 on Employment (Supplement Number 4297 to the State Gazette of the Republic of Indonesia Year 2003 Number 39) did not have binding legal force as long as it is not interpreted that "the payment of the indebted wages of the workers should take precedence over all types of creditors including the bills of the separated creditors, the bills of the State rights, the bills of the auction offices and the state formed enterprises, while the payment of the rights of other workers took precedence over all bills including the bills of the State rights, the bills of the auction offices and the state formed enterprises, except the bills of the separated creditors".

The Constitutional Court Decision hereinabove placed the payment of the indebted wages of the workers should take precedence over all types of creditors including the bills of the separated creditors. This decision is certainly very appropriate because it sided with the workers or the laborers who had a weak position in every aspect. However, the court's decision to place payments on the other workers' rights, such as severance pay, gratuity, and compensation pay that stipulated the payment of such rights under the bills of the separated creditors is less precise, the workers' rights should be paid in advance before the payments of the bills from the separated creditors.

After the Constitutional Court Decision Number 67/PUU-XII-2013, the Commercial Court decisions related to the bankruptcy could not put indebted wages and other rights of the 
workers/laborers below the other creditors such as the separated creditors, the bills of the State rights, the bills of the auction offices, etc. The same thing is stated by a civil law expert from university of Diponegoro named Dr.Yunanto, S.H., M.Hum who said that the principle of justice should be enforced in order to place the wages of the workers or laborers owed at the top position for repayment of debts of bankrupt properties ${ }^{20}$.

In addition to that, there is an opinion from a tax law expert named Dr. Budi Ispriarso S.H., M.Hum. who is at first stated that one of the debts of bankrupt properties whose payments should be prior to the owed wages of the workers/laborers is the bill of the State right (tax debts) because according to the person concerned taxes are the State incomes which would be used to fund the development or government activities including to deal with unemployment issues ${ }^{21}$.

Concerning the obligation to pay off the debts of the bankrupt properties, a tax practitioner namely Muhammad Yusuf stated that the Constitutional Court Decision Number 67/PUU-XII-2013 which in essence determined that the payments of the workers' or laborers' owed wages which are prior to all types of creditors including the bills of the State rights (tax debts), institutions, or tax offices would obey the court decision ${ }^{22}$. Similarly, a judge named Abdul Rauf S.H. stated that the judges would obey what the Constitutional Court decision is related to the obligation of the payments of the workers' or laborers' owed wages with the bankruptcy company ${ }^{23}$.

According to the researcher, the second point of the Constitutional Court Decision should be the same with the first point of the Constitutional Court Decision which positioned the payments of the owed wages of the laborers and the other debts (severance pay, gratuity, and compensation pay) over the other creditors including the separated creditors, the State rights, etc.

\section{Conclusions}

The regulations of the position of the wages of the workers/laborers and other rights in the process of bankruptcy as referred to in Law Number 37 year 2004 is regulated in Article 39 paragraph (2) which mentioned that the remunerations of the employees shall become a debt of bankruptcy estate. The remunerations of the employees and the other rights shall become the debt of

\footnotetext{
${ }^{20}$ Yunanto,interview to the experts of civil law from UNDIP, Semarang, 25 ${ }^{\text {th }}$ June 2017

${ }^{21}$ Budi Ispriarso,interview, Taxation Law Theoretician, Law Faculty,Universitas Diponegoro, Semarang, $25^{\text {th }}$ June 2017

${ }^{22}$ Muhammad Yusuf, Interview, Taxation Practitioner of Tax Directorate, Surabaya, 30 $0^{\text {th }}$ June 2017

${ }^{23}$ Abdul Rauf, Interview, Vice Head of Ungaran Region Courts, Semarang, $15^{\text {th }}$ July 2017
} 
bankruptcy estate as from the date of the bankruptcy declaration. The wages and other rights owed before and after the pronouncement of bankruptcy declaration decision shall become the debt of bankruptcy estate. The wages of the workers or laborers are broadly defined as debts which are paid in accordance with a work agreement. The Law does not explicitly regulate the wages of the workers or laborers represented by the position of the workers/laborers which are included in the level of privileged separated creditors or concurrent creditors. On the other hand, as set forth in Article 95 paragraph (4) Law number 13 year 2003 it is stated that in case the enterprise is declared bankrupt or liquidated based on valid statutory legislation, the payment of the enterprise's workers/laborers' wages shall take priority over the payment of other debts. The further regulation is in Article 37 paragraph (1), (2), and (3) of the Government Regulation of the Republic of Indonesia number 78 Year 2015.

In some bankruptcy cases in Indonesia, the basis of the judge's decision has stipulated the remunerations of the employees and the other rights as the debt of bankruptcy estate and mostly stipulated the workers/laborers as preferred creditors with common privileges, not separated creditors or even concurrent ones. Notwithstanding, after the pronouncement of the Constitutional Court Decision Number 67/PUU-XII-2013 positioned the workers/laborers with special privileges over the separated creditors limited to the wages owed; on the other hand, the severance pay, gratuity and compensation pay are still paid off after the separated creditors.

\section{Suggestions}

After the pronouncement of the Constitutional Court Decision Number 67/PUU-XII-2013 the judges are obliged to hold a hearing on the petition for a declaration of bankruptcy which should be pursuant to the Constitutional Court Decision including the Curators obliged to obey and comply with that decision.

\section{References}

E. Levinthal, Louis. 1993. The Early History of Bankruptcy Law in Jordan et al. Bankruptcy.New York : Foundation Press.

Ginting, Ramlan. 2001. Kewenangan Tunggal Bank Indonesia Dalam Kepailitan Bank. "Buletin Hukum Perbankan dan Kebanksentralan”, Vol.2 No.2, mengutip dari W.J.S.

Poerwadarminta. 1999. Kamus Umum BahasaIndonesia, Balai Pustaka: Jakarta. 
Hartini,R. 2007. Hukum Kepailitan.Malang: UMM Press.

Ispriarso, Budi. Wawancara Teoritisi Hukum Pajak. Fakultas Hukum. Universitas Diponegoro. Semarang, 25 Mei 2015.

Jono. 2008. Hukum Kepailitan. Jakarta: Sinar Grafika.

Mahfud MD, Moh. 2000. Dasar dan Struktur ketatanegaraan Indonesia (edisi revisi). Jakarta: Renaka Cipta.

Muhammad, Abdulkadir. 2004.Hukum dan Penelitian Hukum. Bandung: PT. Citra Aditya Bakti.

Muljadi,Kartini. 2004.Kreditor Preferens dan Kreditor Separatis Dalam Kepailitan," UndangUndang Kepailitan danPerkembangannya: Prosiding Rangkaian Lokakarya Terbatas MasalahMasalah Kepailitan dan Wawasan Hukum Bisnis Lainnya Tahun 2004 : Jakarta 26-28 Januari 2004”, Jakarta:Pusat Pengkajian Hukum, 2005, hlm. 65. lihat pasal 1133, 1134 KUH Perdata

Muljadi, Kartini dan Widjaja,Gunawan. 2003.Pedoman Menangani PerkaraKepailitan. Jakarta: Rajawali Press.

Muslimin, Amrah.1 985. Berapa Asas dan dan Pengertian Pokok Tentang Administrasi dan Hukum Administrasi. Bandung: AlumniBandung.

Pudyatmoko, YSri. 2009. Perizinan,Problem dan Upaya Pembenahan. Jakarta : Gramedia Pustaka Widiarsana Indonesia.

Rauf, Abdul. Interview, Vice Head of Ungaran Region Courts, Semarang, 15 $5^{\text {th }}$ July 2017

Soekanto, Soerjono. 1986. Pengantar Penelitian Hukum. Jakarta : UI Press.

Sunarni. 2004. Perbandingan Sistem Hukum Kepailitan antara Indonesia (Civil Law System) dengan Amerika Serikat (CommonLaw System). (Fakultas Hukum Unversitas Sumatera Utara) quoted from Douglas G. Bird, 1985. Cases, Problems, and Materials on Bankruptcy. Boston, USA : Little, Brown and Company.

Yani A \& Widjaja Gunawan. 2004. Seri Hukum Bisnis Kepailitan. Jakarta: PT.Raja Grafindo Persada.

Yunanto,interview to the experts of civil law from UNDIP, Semarang, $25^{\text {th }}$ June 2017

Yusuf, Muhammad. Interview, Taxation Practitioner of Tax Directorate, Surabaya, 30 ${ }^{\text {th }}$ June 2017 